\title{
Impact of Incentives on Job Satisfaction of Employees in the Vehicle Emission and Test Industry
}

\author{
Krishan Kumarapeli
}

\begin{abstract}
This investigation is carried out two employee categories of technicians and mechanics are identified in the two major companies of laughs and drive green in this Industry. Poor work performance and high labor turnover among technicians and mechanics in the industry emerge the necessity of conduct this investigation. The independent Variable or incentives and dependent variable of job satisfaction are extracted through different literatures and empirical studies. Simple random sampling was taken place taken from 800 population and 200 employees were selected. Interviews and structured questionnaires were used as the tools of the analysis. The analyses find moderate positive relationship between financial incentives and job satisfaction. Rather strong moderate positive relationship existed between nonfinancial incentive and job satisfaction.
\end{abstract}

Key Words: Financial Incentives, Non-Financial Incentives, Reward, Motivation Job satisfaction

\section{INTRODUCTION}

This investigation is carried out to survey on the impact of incentives on job satisfaction of employees in the vehicle emission test industry. This research is designed with quantitative research using the deductive approach. The poor job satisfaction of employee has been identified as a heavy issue in most companies. The main aim of modern organizations is maximization profitability. The adverse work conditions in the vehicle emission test industry caused dissatisfaction among technicians and mechanics.The stress and depression which common among all such employees have led to mental agony and job dissatisfaction. As a result high labor turnover which ultimately have put the vehicle emission test industry in a jeopardy and adversely affect economic growth and progress of the country.

\section{PROBLEM STATEMENT}

The dissatisfaction among technicians and mechanics in vehicle emission test industry is the main issue in such companies. [1] States dissatisfied technicians in vehicle emission test industry led in poor performance in such companies whereas the survival of the company is highly depended on performance of technicians who contribute mainly to the profitability of the company.

Krishan Kumarapeli is with the Universityof Kelaniya, Kandy Road, Dalugama

\section{A. Research Gap}

The lack of investigations carried out seeking the relationship between reward systems and employee dissatisfaction in the area of Vehicle emission test industry in Sri Lankan context pave the way for proceed this study.

\section{B. Research Questions}

Research questions were emerged in following four aspects

1) What is the impact of financial and nonfinancial incentives on job satisfaction?

2) What is the relationship between financial and non-financial incentives and job satisfaction?

3) What is the level of job satisfaction?

4) What are the recommendations to improve job satisfaction

\section{Objectives}

To ascertain the impact of incentives on job satisfaction of employees in the vehicle emission test industry, following objectives were identified.

1) To identify the impact of financial and non financial incentives on job satisfaction

2) To identify the relationship between financial and non-financial incentives and job satisfaction.

3) To measure the level of job satisfaction

4) To make recommendations to improve job satisfaction

\section{LITERATURE REVIEW}

The theoretical perspectives of various HR theorists are explained with literature in this study. The chapter contains mainly with four parts in relation to 1) incentives, 2) theories related to job satisfaction with views of experts and practitioners in $\mathrm{HR}$ and 3) the relationship between job satisfaction and incentives and finally the 4) theoretical framework. According to [2] non-financial incentives are vital and prominent as an incentive which although not directly provide benefits to employees in terms of cash. [3] states the employees are satisfied with both financial and nonfinancial incentives. The incentives links to employees' performance lead to job satisfaction. According to [2] the gap between capacity and willingness to work depend mainly upon strength of the incentives. [4] Categorizes incentives mainly into two as financial and non-financial incentives. [5] States performance of employees are highly 
correlated to motivation which lead job satisfaction [6] States employee commitment and dedication are major aspects of any company to accomplish its mission. According to [7] employers pay performance bonuses to employees who mark high ratings in performance appraisals. The Non-financial incentives do address employees' psychological and social needs in greater extent [8]. According to [9] at some companies recognize employees' achievements, experience and educational qualifications. [10] Emphasizes gained achievement by an employee not only contribute for the benefit of the company but enable to improve inner skills and core competences to prepare him for the next level. According to [11] process theories are explanations how individuals are satisfied. According to [12] four important theories describe how motivation occurs: Porter-Lawler theory, Needs-goal theory, Equity Theory Vroom expectancy theory. According to [8] when the hygiene factors of a particular job situation are undesirable, organization members will become dissatisfied. According to [13] Alderfer's ERG theory is similar to Maslow's theory except in three major respects and concluded that movement in his hierarchy of human needs is not always upward. Maslow states that human beings possess the five basic needs arrange in a hierarchy of importance- the order in which individuals generally strive to satisfy them. [12],[14] Emphasizes the progress of organizations has dealt with business strategies to motivate employees through incentives systems

\section{METHODOLOGY}

The analysis was done using descriptive statistics and inferential statistics of Pearson correlation coefficient and regression analysis. Data gathered using standard questionnaire which formulated five point Likert scale.

\section{A. Sampling and Population}

The sample size was 200 extracted from the population of 800 employees.The simple random sampling technique was apllied for deriving the sample based on the employee registers in the core vehicle emission test service providers namely Drive Green and Laughfs. The sample was represented by $25 \%$ of the population .

\section{B. Research Design}

In conducting analysis of data of this research the correlation and regression have to be measured .Here incentives are taken as the independent variable and job satisfaction as the dependent variable. As expounded in detail under the conceptual framework and in the development of hypotheses, firstly the relationship between overall rewards and job satisfaction is to be determined, then the relationship between financial incentives and non-financial incentives with job satisfaction is to be determined .Thus it will enable to determine the relationship that exist as a whole between overall rewards and job satisfaction and relationship between financial and non-financial incentives with job satisfaction with the use of correlation and regression analysis. The conceptual framework can be depicted as given in the figure number 1 .

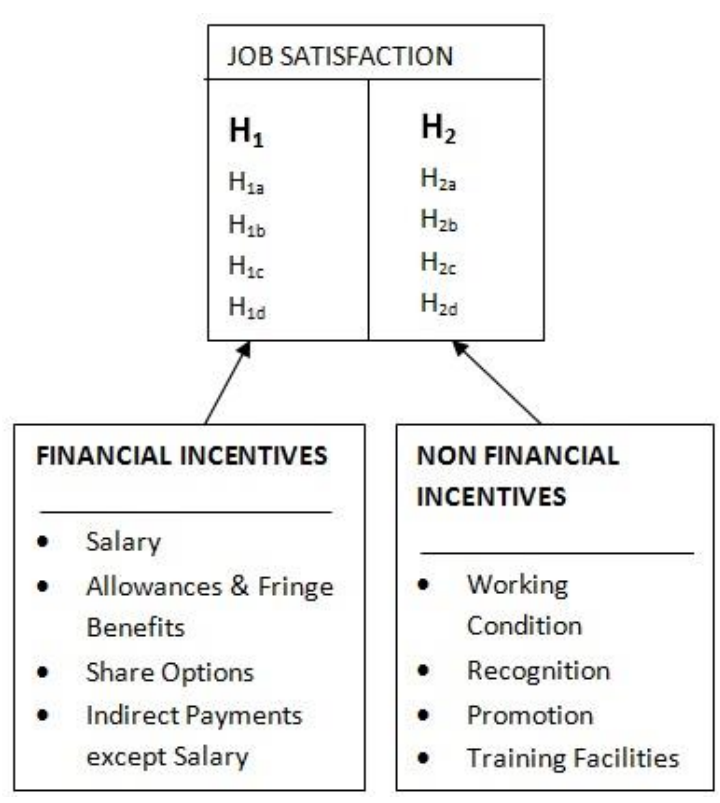

Fig. 1: Conceptual Framework

\section{Hypotheses of the study}

Based on the conceptual framework and according to the literatures and models, which are discussed; the following hypotheses were developed for the testing by the research person.

$\mathbf{H}_{1}$ : There is a positive relationship between Financial Incentives and Job Satisfaction

$\mathrm{H}_{1}$ will be tested as follow,

$\boldsymbol{H}_{1 a}$ : There is a positive relationship between Salary and Job Satisfaction

$\boldsymbol{H}_{1 b}$ : There is a positive relationship between 'allowances and fringe benefits' and Job

Satisfaction

$\boldsymbol{H}_{1 c}:$ There is a positive relationship between share options and Job satisfaction

$\boldsymbol{H}_{1 d}$ : There is a positive relationship between indirect payments other than salary and Job satisfaction

H2: There is a positive relationship between Non Financial Incentives and Job Satisfaction $\mathrm{H}_{1}$ will be tested as follow,

$\boldsymbol{H}_{2 a}$ : There is a positive relationship between working conditions and Job satisfaction

$\boldsymbol{H}_{2 b}$ : There is a positive relationship between recognition and Job satisfaction

$\boldsymbol{H}_{2 c}$ : There is a positive relationship between Promotions and Job satisfaction

$\boldsymbol{H}_{2 d}$ : There is a positive relationship between Training Facilities and Job satisfaction 


\section{Data Collection}

The sources of secondary data account to $80 \%$ of this research. The main sources of secondary data are available in the intranet, HR records, reports of Drive Green and Laugh gas prepared at functional level by different departments to ascertain the adequacy of incentives to satisfy employees for over a period of time. The available information is adequate to meet the requirements to conduct this study. The secondary data as main source of information has been gathered and collected frequently over a period of five years. The various reports relevant to this ongoing issue has been compiled by committed and responsible employees who have been authorized for the preparation of required reports within stipulated time period with board approval. The information contained in those reports is true, correct and accurate which were subject to disclosure for the benefit of the company and employees without being made confidential. Therefore, as information available in the reports is not subject to non-disclosure or confidential clauses the publication of such information is not restricted and permissible by the company.

\section{FINDINGS AND DISCUSSION}

It has been evident as exhibit in table 1 moderate positive correlation that exists between financial incentives and job satisfaction.

TABLE I

PEARSON CORRELATION COEFFICIENT BETWEEN FINANCIAL INCENTIVES \& JOBSATISFCATION

\begin{tabular}{|c|c|c|c|}
\hline & & $\begin{array}{c}\text { Financial } \\
\text { Incentives }\end{array}$ & $\begin{array}{c}\text { Job } \\
\text { Satisfaction }\end{array}$ \\
\hline $\begin{array}{c}\text { Financial } \\
\text { Incentives }\end{array}$ & $\begin{array}{c}\text { Pearson } \\
\text { Correlation } \\
\text { Sig. (2-tailed) } \\
\text { N }\end{array}$ & 200 & $\begin{array}{l}.513^{* * *} \\
.000 \\
200\end{array}$ \\
\hline Job Satisfaction & $\begin{array}{c}\text { Pearson } \\
\text { Correlation } \\
\text { Sig. (2-tailed) }\end{array}$ & $\begin{array}{l}.513^{* *} \\
.000 \\
200\end{array}$ & . \\
\hline
\end{tabular}

There is a strong positive relationship between non-financial incentives and job satisfaction as exhibit in table 2.
TABLE II PEARSON CORRELATION COEFFICIENT BETWEEN NON FINANCIAL INCENTIVES \& JOBSATISFCATION

\begin{tabular}{|c|c|c|c|}
\hline & & $\begin{array}{c}\text { Non-Financial } \\
\text { Incentives }\end{array}$ & $\begin{array}{c}\text { Job } \\
\text { Satisfaction }\end{array}$ \\
\hline $\begin{array}{l}\text { Non-Financial } \\
\text { Incentives }\end{array}$ & $\begin{array}{l}\text { Pearson Correlation } \\
\text { Sig. (2-tailed) } \\
\text { N }\end{array}$ & 200 & $\begin{array}{l}.732^{* *} \\
.000 \\
200\end{array}$ \\
\hline Job Satisfaction & $\begin{array}{l}\text { Pearson Correlation } \\
\text { Sig. (2-tailed) } \\
\text { N }\end{array}$ & $\begin{array}{l}.732^{* *} \\
.000 \\
200\end{array}$ & $\left.\right|_{200} ^{1}$ \\
\hline
\end{tabular}

In this study linear regression was used as a model to develop the regression equation.

TABLE III

REGRSSION OF INCENTIVES \& JOB SATIFACTION

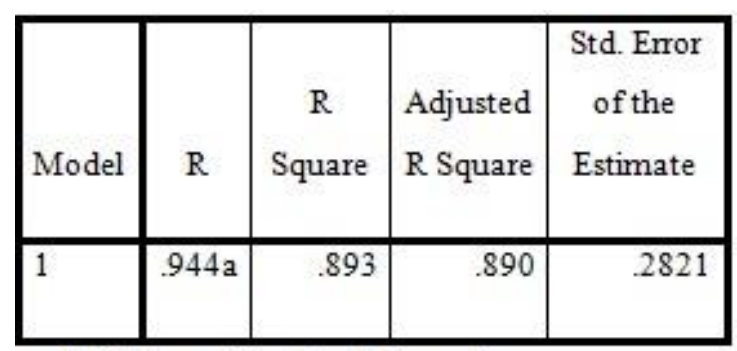

a. Predictors: (Constant), Rewards

In ascertaining the regression between Overall incentives and Job Satisfaction model summary table 3 indicated that the $\mathrm{R}$ square value as 0.893 and adjusted $\mathrm{R}$ square value of 0.890 . In this model summary table, $\mathrm{R}$ square ascertains the total variability of dependent variable as explained by the independent variable. As $\mathrm{R}$ square value was 0.893 would mean $89.3 \%$ of total variability of dependent variable explained by independent variable.

\section{A. Pearson Correlation Analysis for Sub Variables}

TABLE IV: PEARSON CORRELATION COEFFICIENT BETWEEN FINANCIAL INCENTIVES SUB VARIALES \& JOBSATISFCATION

\begin{tabular}{|l|l|r|r|}
\hline & & Sub Variable & Job Satisfaction \\
\hline Financial & Pearson Correlation & 1 & $.513^{* *}$ \\
\cline { 3 - 4 } Incentives & Sig. (2-tailed) & & .000 \\
\hline Salary & Pearson Correlation & 1 & $.611^{* *}$ \\
\cline { 3 - 4 } & Sig. (2-tailed) & & .000 \\
\hline Share & Pearson Correlation & 1 & $.723^{* *}$ \\
\cline { 3 - 4 } Options & Sig. (2-tailed) & & .000 \\
\hline Allowances & Pearson Correlation & 1 & $.769^{* *}$ \\
\cline { 3 - 4 } $\begin{array}{l}\text { \& Fringe } \\
\text { Benefits }\end{array}$ & Sig. (2-tailed) & \multicolumn{2}{|c}{} \\
* & & .000 \\
\hline
\end{tabular}

According to the findings we can conclude that all sub hypotheses can be accepted under $\mathbf{H}_{1}$ with in the 99\% confident level. 
TABLE V: PEARSON CORRELATION COEFFICIENT BETWEEN FINANCIAL INCENTIVES SUB VARIALES \& JOBSATISFCATION

\begin{tabular}{|c|c|c|c|}
\hline & & Sub Variable & Job Satisfaction \\
\hline \multirow[t]{2}{*}{ Recognition } & \multirow{2}{*}{$\begin{array}{l}\text { Pearson Correlation } \\
\text { Sig. (2-tailed) }\end{array}$} & 1 & $.687^{* *}$ \\
\hline & & & .000 \\
\hline \multirow{2}{*}{$\begin{array}{l}\text { Working } \\
\text { Conditions }\end{array}$} & \multirow{2}{*}{$\begin{array}{l}\text { Pearson Correlation } \\
\text { Sig. (2-tailed) }\end{array}$} & 1 & $.642^{* * *}$ \\
\hline & & & .000 \\
\hline \multirow[t]{2}{*}{ Promotions } & \multirow{2}{*}{$\begin{array}{l}\text { Pearson Correlation } \\
\text { Sig. (2-tailed) }\end{array}$} & 1 & $.721^{* *}$ \\
\hline & & & .000 \\
\hline \multirow{2}{*}{$\begin{array}{l}\text { Training } \\
\text { Facilities }\end{array}$} & \multirow{2}{*}{$\begin{array}{l}\text { Pearson Correlation } \\
\text { Sig. (2-tailed) }\end{array}$} & 1 & $.606^{* *}$ \\
\hline & & & .000 \\
\hline
\end{tabular}

According to the findings we can conclude that all sub hypotheses can be accepted under $\mathbf{H}_{2}$ with in the 99\% confident level.

\section{CONCLUSION}

In the analysis of results it was quite evident that overall incentives have strong positive relationship with job satisfaction, thereafter the results also indicated both financial including salary, share options, allowances and fringe benefits and indirect payments other than salary (bonuses and overtime) and non-financial incentives including working conditions, recognition, promotions and training facilities also have a strong positive relationship with job satisfaction. However non-financial incentives were more effective than financial incentives were proven by findings of the research.

\section{A. Recommendations}

The management should take measures to enhance job satisfaction in making employees to stay with their employer while provision of work and achievements. More steps have to be taken to provide recognition measures such as selection of the best employee of the month, awards ceremonies, gettogethers, excursions, foreign tours.

Conducive working conditions are established through proper ventilation, intensity of lighting and illumination, canteen facilities, wash rooms and rest rooms, health and safety assurance, furniture and equipment with proper ergonomics, safety tools such as helmets, gloves, eyewear etc., emergency fire exit, hygienic sanitation facilities has to be provided by employers in vehicle emission test industry as facilities for high standard of works.

Different aspects of job training is vital in creating employee satisfaction as technical, mechanical and executive training programs, provision of foreign training and adoption of advanced technological training of equipment and machinery, workshops, seminars, classroom lectures to promote learning and technical skills etc.

Periodically review existing remuneration policies and procedures, administrative changes and amendments and also rectification of work practices to give more concern on incentives oriented performance which is to make employees in the vehicle emission test industry to commit them to organizational success. In this regard proper organizational structure, rules and regulations, ethics, procedures and practices on promotions and organizational culture should be changed as the evolution of the organization to make the organization productive and to create work friendly culture.

\section{B. Future Investigations}

Future investigation may focus on the factors other than financial and non-financial incentives which cause for employee retention. The investigations may change direction as using data from the companies in the industry other than the two selected for this investigation.

\section{REFERENCES}

[1] Ciscel, H. D. (1974) Determinants of executive compensation, Southern economic Journal, 40(4), 613-617. https://doi.org/10.2307/1056379

[2] Thomas, K.W. (2010) Intrinsic Incentives at Work: Building Energy and Commitment, Soft Skull Publications, Brooklyn

[3] Podmoroff, D. (2009) 365 Ways to Satisfy and Reward Your Employees Every Day: With Little or No Money, Quiver Publications, Beverly.

[4] Nelson, B. (2009) 1001 Ways to Energize Employees, Square One Publishers, Inc, New York

[5] Weiss, J. (1996) Organizational behavior and change : Managing diversity, Cross-cultural dynamics, and ethics, $2^{\text {nd }}$ edition, Vikas Publishing House.

[6] Deeprose, D. (2009) How to recognize and reward employees: 150 ways to inspire peak performance (worksmart), Summertown Publishing Ltd.

[7] Meyer, M., \& Kirsten, M. (2005). Introduction to Human Resource Management. Claremont: New Africa Books (Ptv) Ltd.

[8] Herzberg, F. (2010) One More Time : How Do You Motivate and Reward Employees? (Harvard Business Review Classics), Guideposts, New York.

[9] Bowen, B. (2010) Recognizing and Rewarding Employees, North Atlantic Books, Berkely.

[10] Wilson, T. B. (1994). Innovative reward systems for the changing workplace. United States of America: R.R. Donnelley\& Sons Company.

[11] Bruce, A. (2010) Motivating Employees, Periplus Publishing Group, North Claredon.

[12] Beck, R.C. (2008) Motivation : Theories and Principles, Hyperion, Inc, New York.

[13] Vijayakumar, K. (2009) Rewards and Motivation : Human Resource Management, Institute of Personnel Management.

[14] Lawler, E. E. (2003). Treat people right. San Francisco: Jossey-Bass Inc. McGraw-Hill Irwin 